\begin{tabular}{|l|l|l||}
\hline \multicolumn{2}{|c|}{ PublisherInfo } \\
\hline \hline PublisherName & $:$ & BioMed Central \\
\hline \hline PublisherLocation & $:$ & London \\
\hline \hline PublisherImprintName & $:$ & BioMed Central \\
\hline \hline
\end{tabular}

\title{
Drosophilagenome sequence
}

\begin{tabular}{|l|l|l||}
\hline \multicolumn{2}{|c|}{ ArticleInfo } \\
\hline \hline ArticleID & $:$ & 3572 \\
\hline \hline ArticleDOI & $:$ & $10.1186 /$ gb-2000-1-1-reports038 \\
\hline \hline ArticleCitationID & $:$ & reports038 \\
\hline \hline ArticleSequenceNumber & $:$ & 63 \\
\hline \hline ArticleCategory & $:$ & Paper report \\
\hline \hline ArticleFirstPage & $:$ & 1 \\
\hline \hline ArticleLastPage & $:$ & 4 \\
\hline \hline & & RegistrationDate : 2000-3-24 \\
ArticleHistory & $:$ & Received \\
& $:$ 2000-3-24 \\
\hline \hline ArticleCopyright & $:$ & BioMed Central Ltd2000-5-11 \\
\hline \hline ArticleGrants & $:$ & \\
\hline \hline \hline ArticleContext & $:$ & 130591111 \\
\hline \hline
\end{tabular}




\section{Alan Shirras}

\section{Abstract}

The nucleotide sequence of the 120 megabase euchromatic region of the Drosophila melanogaster genome is reported.

\section{Significance and context}

The completion of the Drosophila melanogaster genome sequence is a significant milestone for several reasons. First, it is the culmination of almost a century of genetic and molecular studies of this model organism; second, it has allowed the applicability of whole-genome sequencing to complex multicellular eukaryotic genomes to be tested; and third, it allows meaningful comparisons with the already sequenced Caenorhabditis elegans and Saccharomyces cerevisiae genomes to be made. Finally, the identification and annotation of Drosophila gene sequences will provide the basis for many future studies.

\section{Key results}

Whole-genome sequencing was carried out by cloning size-selected, randomly sheared Drosophila genomic DNA into plasmid vectors and determining approximately 500 base pairs of sequence from either end. Overlapping stretches of sequence were then assembled into contiguous lengths. A crucial feature of this process was the use of the 'mate pairs' - stretches of sequence from either end of each clone - to minimize the problems of placing sequences containing repetitive DNA. The overall structure of the assembly was confirmed by linking the data to end-sequence information from bacterial artificial chromosomes (BACs) generated by the Berkeley Drosophila genome project (BDGP). This yielded 114.8 megabases $(\mathrm{Mb})$ of sequence that could be unambiguously placed onto chromosomes. Clonebased sequence from the BDGP and the European Drosophila genome project (EDGP) allowed a further $1.4 \mathrm{Mb}$ to be placed on chromosome arms. Roughly 3.8 Mb of sequence, probably representing islands of unique sequence within heterochromatin, could not be placed accurately on the map. By comparison with regions of high-quality sequence already determined by other methods, the whole-genome sequencing was found to be $99.99 \%$ accurate in non-repetitive regions. As a measure of the completeness of the sequence, $97.5 \%$ of sequenced Drosophila genes are found in the assembled sequence. Gene prediction by computational analysis followed by human curation has identified 13,601 genes. Of these, $23 \%$ do not match sequences from other organisms or from Drosophila expressed 
sequence tags (ESTs) and are therefore potentially novel genes. Comparison of gene sequences with other species in general reveals a high degree of conservation although there are some exceptions; for example, several proteins involved in DNA repair are missing from Drosophila. A large number of transcription factors have been identified, suggesting complex networks of gene regulation, and solute transporters are also notable for their abundance and variety.

\section{Links}

Coding content of the fly genome is summarized at the Science website. The CeleraScience website has Drosophila sequences for download as well as commentary on the Drosophila sequencing project. The Drosophila melanogaster genome sequence is also available from GenBank. The GadFly: Genome annotation database of Drosophila is available at Flybase.

\section{Conclusions}

On the basis of their experience with Drosophila the authors point out that the BAC end-sequences and sequence-tagged sites (STS) content map were most cost-effective for long-distance sequence-based information and were necessary to link assemblies to chromosomal locations. A higher density of BAC end-sequences would have allowed larger sequence assemblies at lower shotgun coverage, and they recommend this for future projects.

\section{Reporter's comments}

This sequence is of major benefit to Drosophila researchers among others and will open up many new avenues of research. Although considered "Release 1" by the authors, it is substantially complete and accurate. The whole-genome sequencing strategy has been shown to be applicable to a complex genome, and it seems likely that it will not be long before larger genomes, including the human, are completed in this fashion.

\section{Table of links}

Science

Berkeley Drosophila genome project 
European Drosophila genome project

Coding content of the fly genome

CeleraScience

Drosophila melanogaster genome

GadFly: Genome annotation database of Drosophila

\section{References}

1. Adams MD, Celniker SE, Holt RA, Evans CA, Gocayne JD, Amanatides PG, Scherer SE, Li PW, Hoskins RA, Galle RF, et al: The genome sequence of Drosophila melanogaster. Science. 2000, 287: 2185-2195. 0036-8075

This PDF file was created after publication. 